YIELD AND WATER USE EFFICIENCY OF DEFICIT-IRRIGATED MAIZE IN A SEMI-ARID REGION OF ETHIOPIA

\title{
Yenesew $M^{1}$ and $K$ Tilahun ${ }^{1,2} *$
}

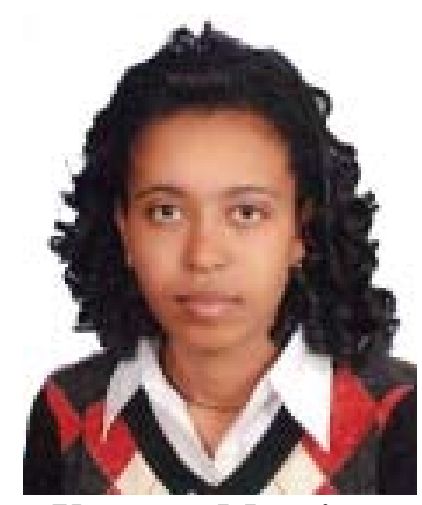

Yenesew Mengiste

*Corresponding author email: ketematilahun@yahoo.com

${ }^{1}$ Haramaya University, P. O. Box 45, Haramaya University, Ethiopia

${ }^{2}$ School of Agricultural and Wine Sciences, Charles Sturt University, Wagga Wagga, NSW, Australia. 


\section{ABSTRACT}

Scarcity of water is the most severe constraint for development of agriculture in arid and semi-arid areas. Under these conditions, the need to use the available water economically and efficiently is unquestionable. Based on the actual crop need, the irrigation management has to be improved so that the water supply to the crop can be reduced while still achieving high yield. The purpose of this study was to determine the water use efficiency of maize (Katumani cultivar) under deficit irrigation practice and to identify crop growth stages during which the crop can withstand water stress with limited effect on yield. The field experiment was conducted at the experimental farm of Haramaya University located in Dire Dawa, Ethiopia. The treatments consisted of ten different levels/timings of irrigation water application. Treatments T1 and $\mathrm{T} 2$ were respectively normal irrigation and $75 \%$ deficit irrigation throughout the growing season. T3, T4, T5, and T6 were stressed by $75 \%$ at a specific stage: initial stage, development stage, mid season stage, and late season stage respectively. T7, T8, T9, and T10 were stressed by 50\% at the respective four growth stages. The result showed that variation in level (amount) of irrigation water application had a significant impact on grain yield. In the case of stress by $75 \%$ deficit at a specific stage, the effect of stress was severe during the mid season stage. The mid season stage was the most sensitive to water stress. On the other hand, water deficit during the early and maturity stage had a limited effect on yield. Stressing the crop by $75 \%$ deficit throughout the growing season resulted in the highest yield reduction. However, the crop water use efficiency was the lowest $\left(1.72 \mathrm{~kg} / \mathrm{m}^{3}\right)$ at optimum irrigation water application and the highest $\left(2.96 \mathrm{~kg} / \mathrm{m}^{3}\right)$ at stress of $75 \%$ deficit throughout the growth season. Although at individual farmer's level, maximum yield is obtained when the entire crop water requirement is fulfilled, practicing deficit irrigation could increase the irrigated area as a result of high water use efficiency.

Key words: deficit irrigation, water use efficiency 


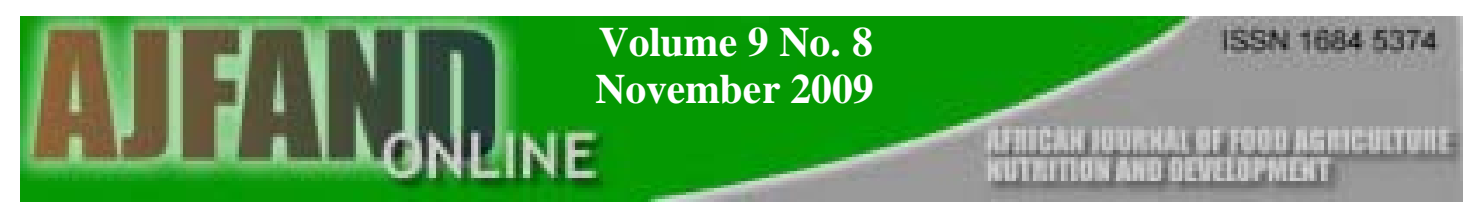

\section{INTRODUCTION}

Ethiopia receives an apparently adequate rainfall for crop production if one considers country-wide average annual rainfall. However, the production of sustainable and reliable food supply is becoming almost impossible due to temporal and spatial imbalance in the distribution of rainfall and the consequential non-availability of water at the required period. Often, crop failure occurs because of unavailability of water at some critical growth stages. To curb such conditions, and improve water productivity, there is a growing interest in deficit irrigation, an irrigation practice whereby water supply is reduced below maximum level and mild stress is allowed with minimal effect on yield.

Under conditions of scarce water supply and drought, deficit irrigation can lead to greater economic gain by maximizing water use efficiency. The term water use efficiency is used to describe the relation between crop yield and water use [1,2]. Increasing the amount of water used by the plant or increasing the yield of the plant can change water use efficiency. In this context, deficit irrigation provides a means of reducing water consumption while minimizing adverse effects on yield [3]. However, this approach requires precise knowledge of crop response to water as drought tolerance varies considerably by growth stage, species and cultivars. The optimum scheduling of irrigation for specified level of deficit water supply is determined by evaluating the effect of missed irrigation on crop yield [4]. Identifying growth stages of particular crops under local conditions of climate and soil fertility allows irrigation scheduling for maximum crop yield and most efficient use of scarce water resource.

Maize (Zea Mays L.) is one of the most important food crops worldwide. It has the highest average yield per hectare and is the third after wheat and rice in area and total production in the world. In Ethiopia, it is one of the leading food grains selected to assume a national commodity crop to support the food self-sufficiency program of the country [5]. Maize is fairly sensitive to water stress [6, 7]. Excessive moisture stress is the most limiting factor in maize production [8]. During establishment, it kills young plants and reduces plant density. During vegetative stage, it restricts leaf growth and expansion so resulting in stunted growth $[8,9]$. With increasing moisture stress, the dry matter production of the crop decreases directly by decreasing cell division and enlargement and indirectly by reducing rate of photosynthesis [10]. Much of the past research on water stress on maize has consisted of full withholding of irrigation and conditions of severe water stress $[11,12,13]$. At the same time, there is also indication that maize yield is just a linear function of seasonal evapo-transpiration [14, $15,16,17]$. Deficit irrigation of maize distributed over the whole growing season might not always result in increasing crop water productivity [16]. This is due to variation in sensitivity of different growth stages to water stress. It is essential to examine the effect of water stress at different growth stages on maize yield. Therefore, it is important to know the crop response to water deficit at different growth stages and under cropping and irrigation conditions of a given area. 
Considering the scarcity of irrigation water in the region and the sensitivity of maize crop to moisture stress, this research was aimed at (1) determining the water use efficiency of maize under deficit irrigation practice and, (2) identifying crop growth stages during which the crop (maize) can withstand water stress with minimal effect on yield.

\section{MATERIALS AND METHODS}

\section{Description of the experimental area}

The experiment was conducted at Haramaya University research site in Dire Dawa (Ethiopia) from October to February 2006/07 a period which is considered to be dry in the area. The experimental site is located at $41^{0} 51^{\prime} \mathrm{E}$ longitude, $9^{0} 31^{\prime} \mathrm{N}$ latitude and at an altitude of $1160 \mathrm{~m}$ above sea level in a semi-arid belt of the eastern rift valley escarpment. The soil texture is clay loam. The area experiences a bimodal type of rainfall with mean annual rainfall of $556 \mathrm{~mm}$. The mean annual maximum and minimum temperatures vary from $28^{\circ} \mathrm{C}$ to $35^{\circ} \mathrm{C}$ and $15^{\circ} \mathrm{C}$ to $23^{\circ} \mathrm{C}$, respectively [18].

\section{Experimental layout and cultural practices}

The experiment was laid out in a Randomized Complete Block Design (RCBD) with three replications. There were ten treatments made by varying the amount of irrigation water throughout the growing season and at specific growth stages (Table 1). The crop growing season was divided into four major growth periods: the initial stage (P1), development stage (P2), mid season stage (P3), and late season (P4). The initial stage (P1) runs from planting date to approximately $10 \%$ ground cover. The crop development stage (P2) is from $10 \%$ ground cover to effective full cover. The midseason stage runs from effective full cover to the start of maturity. The late season stage is from the start of maturity to harvest or full senescence [19]. The treatments were: one treatment with full irrigation throughout the growing season, one treatment with a quarter of the full irrigation $(75 \%$ deficit) throughout the growth season, and eight treatments with a quarter (75\% deficit) and one-half (50\% deficit) of the full irrigation at one of the four growing stages, respectively.

Katumani, an early maturing cultivar of maize, was planted on 21 October 2006 at a spacing of $75 \mathrm{~cm}$ between rows and $25 \mathrm{~cm}$ between plants. The row length was $5 \mathrm{~m}$ and each plot consisted of five ridges and six furrows. The furrow had a ' $V$ ' shape with an average depth of $15 \mathrm{~cm}$ and width of $65 \mathrm{~cm}$ at the top. Fertilizer application was $100 \mathrm{~kg} / \mathrm{ha}$ DAP (20\% phosphorous) applied at planting and $150 \mathrm{~kg} / \mathrm{ha}$ Urea split applied as $1 / 3$ at planting and $2 / 3$ when the plants reached knee height.

\section{Crop water requirement and irrigation scheduling}

Irrigation scheduling was done using the CROPWAT program and adopting the weekly irrigation interval commonly used by the farmers in the area. Crop water 
requirement was calculated using CROPWAT program based on the FAO PenmanMonteith method [9]:

$$
E T_{m}=K_{c} \times E T_{o}
$$

Where $E T_{m}$ is the crop evapotranspiration, $K_{c}$ is the crop coefficient, and $E T_{o}$ is reference crop evapotranspiration. The reference crop evapotranspiration was calculated [19] as:

$E T_{O}=\frac{0.408 \Delta[R n-G]+\gamma\left(\frac{900}{T+273}\right) U_{2}\left[e_{s}-e_{a}\right]}{\Delta+\gamma\left[1+0.34 U_{2}\right]}$

Where $E T_{o}$ is the reference crop evapotranspiration ( $\mathrm{mm} /$ day); $\Delta$ is the slope of the saturation vapor pressure curve $(\mathrm{kpa} 0 / \mathrm{c}) ; R n$ is net radiation at the crop surface $\left(\mathrm{MJ} / \mathrm{m}^{2}\right.$ day); $G$ is the soil heat flux density $\left(\mathrm{MJ} / \mathrm{m}^{2}\right.$ day); $T$ is the mean daily air temperature at $2 \mathrm{~m}$ height $\left({ }^{0} \mathrm{C}\right) ; U_{2}$ is the wind speed at $2 \mathrm{~m}$ height $(\mathrm{m} / \mathrm{s}) ; e_{s}-e_{a}$ is saturation vapor pressure deficit $(\mathrm{kPa}) ; e_{s}$ is the saturation vapor pressure at a given period $(\mathrm{kPa}) ; e_{a}$ is actual vapor pressure $(\mathrm{kPa}) ; \gamma$ is the psychrometric constant $\left(\mathrm{kPa}^{0} / \mathrm{c}\right)$.

Irrigation water use efficiency (WUE) was calculated using the following relation:

IWUE $=\frac{\text { Grain yield }}{\text { Irrigation } \text { water } \text { applied }}$

Table 2 presents irrigation water applied under different irrigation regimes. As treatment 1 was conducted under no water stress, its consumptive water use was considered to be equal to the maximum crop water requirement $\mathrm{ET}_{\mathrm{m}}$. Total $\mathrm{ET}_{\mathrm{m}}$ of maize was $419.2 \mathrm{~mm}$ for the growing period of 95 days. The gross irrigation requirement was computed by adopting a field application efficiency of $60 \%$. Furrow irrigation application efficiencies normally vary from 45-60\% [20]. In this experimental setup, water was applied with precise measurement; furrows were short and end-diked. As a result, there was no run-off and the only loss would be deep percolation which is expected to be not much in a deficit irrigation practice. Therefore, a higher value of application efficiency (60\%) was adopted. Adopting this value of application efficiency, the gross seasonal irrigation requirement for treatment 1 (normal irrigation) was $686.2 \mathrm{~mm}$. The amount of irrigation for other treatments was then calculated. 
Treatment 2 (KT25) was fully stressed (received $25 \%$ of the needed irrigation requirement) throughout the growing season. Treatment $3\left(\mathrm{~T}_{1} 25\right)$, treatment $4\left(\mathrm{~T}_{2} 25\right)$, treatment $5\left(\mathrm{~T}_{3} 25 \%\right)$, and treatment $6\left(\mathrm{~T}_{4} 25 \%\right)$ were stressed at initial stage, development stage, mid season stage, and late season stages respectively. They received only $25 \%$ of the optimum irrigation at the respective growth stages and normal (full) irrigation at other stages. Treatment $7\left(\mathrm{~T}_{1} 50\right)$, treatment $8\left(\mathrm{~T}_{2} 50\right)$, treatment $9\left(\mathrm{~T}_{3} 50\right)$ and treatment $10\left(\mathrm{~T}_{4} 50\right)$ were stressed by one-half $(50 \%$ deficit $)$ at initial stage, development stage, mid season stage, and late season stages, respectively.

\section{Data collection and analysis}

Groundwater was pumped to a water tanker near the experimental farm. At the bottom of the tanker was an opening fitted with a water meter. Based on the pre-prepared irrigation schedule, the amount of water applied to each furrow was measured and conveyed to each furrow using plastic hose.

Grain yield was measured as weight of harvested grain in each plot and adjusted to $12.5 \%$ moisture, then converted to ton per hectare for each treatment. Total biomass yield was determined as the total above ground biological yield (grain and all other parts). Analysis of variance for the design was carried out for the parameters studied following the standard procedures applicable to randomized complete block design (RCBD). When the treatment effects were found significant, mean differences were tested using Duncan's Multiple Range Test (DMRT) at 5\% or 1\% level of probability. Analysis of variance was computed using the MSTATC software.

\section{RESULTS}

Maize crop yields from each treatment are shown in Fig. 1. The average yield was $6.40 \mathrm{t} / \mathrm{ha}$ with a coefficient of variation $\mathrm{CV}$ of $1.76 \%$. Using LSD test, first confirming that the F-test was significant at $5 \%$ and $1 \%$ significance level, it was found that water deficit at the initial stage and late season stage for both $75 \%$ deficit and $50 \%$ deficit, gave non-significantly $(\mathrm{p}>0.05)$ different yields from the optimum application T1 (Table 3. However, for water deficit at the development stage, mid season stage, or during all stages for $75 \%$ deficit throughout the growing season, the yields were significantly different $(\mathrm{p}<0.01)$ from treatment 1 (KT100). Treatments T5 and T9 which were conducted under adequate watering conditions throughout the first two periods of the growing season, and followed by a period of stress at the mid season stage, resulted in the second and the third lowest yields of $5.49 \mathrm{t} / \mathrm{ha}$ and 6.14 $\mathrm{t} / \mathrm{ha}$, respectively. This tendency might be attributed to the fact that adequate watering conditions early in the season led to the development of an abundant leaf cover and a shallow root depth. Maximum yield of Katumani $(7.11 \mathrm{t} / \mathrm{ha})$ was obtained under optimum irrigation (T1). T2 which was subjected to the highest water stress $(75 \%$ deficit) throughout the growth period, resulted in the minimum yield $(3.05 \mathrm{t} / \mathrm{ha})$. 


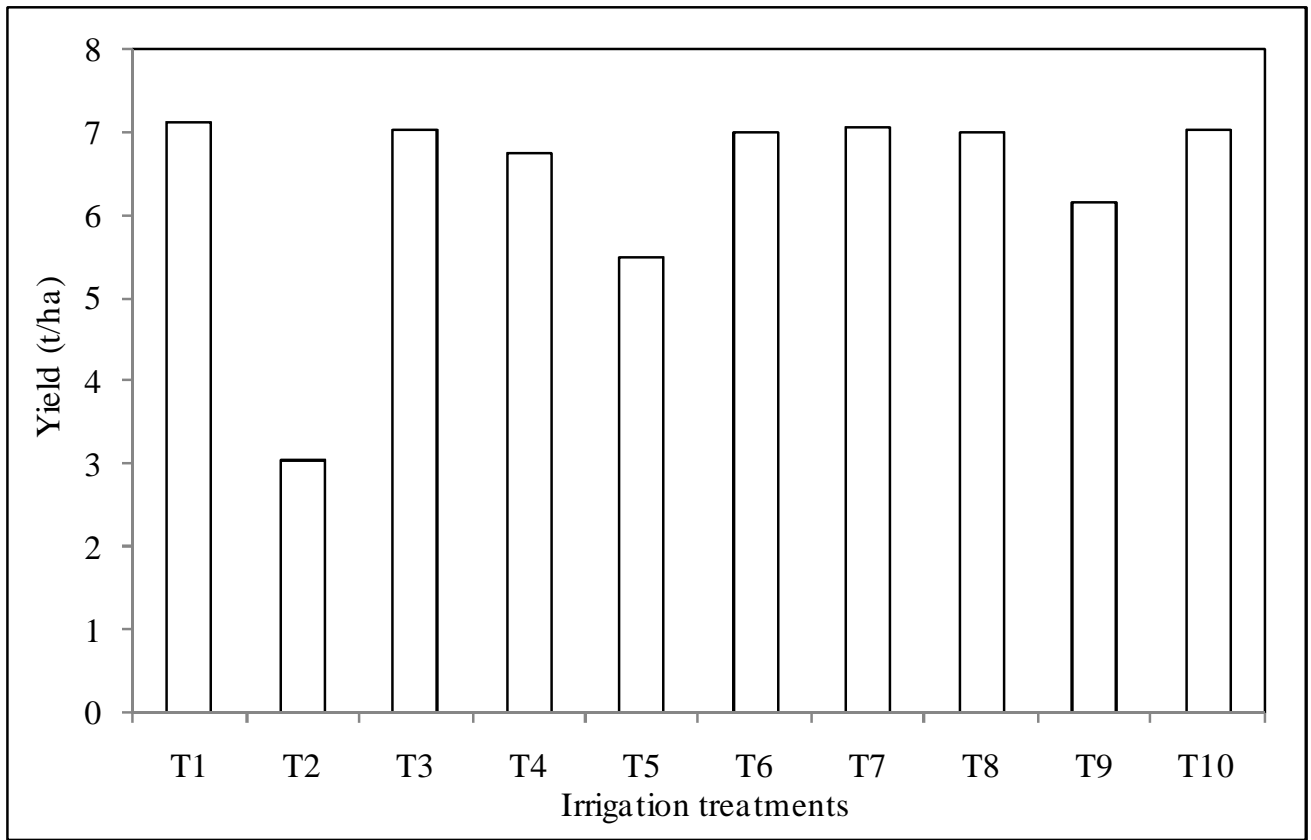

Figure 1: Yield of maize crop under different irrigation treatments

In treatments $\mathrm{T} 6$ and $\mathrm{T} 10$ (75\% and 50\% deficit, respectively at the late season stage), the yield reductions were only $1.7 \%$ and $0.9 \%$ (Table 4 ). This yield reduction would have been much higher had the crop been subjected to water stress during any of the previous stages, especially in the mid season stage. The yield from T2 was much lower than those obtained from treatments with stress at individual growing stage of initial, development, mid season and late season stages. It is better to stress the crop at a specified growing stage of the crop rather than totally stressing throughout the season.

Analysis of variance on dry matter production revealed that variation in level of irrigation water application significantly $(\mathrm{p}<0.01)$ influenced the dry mater production. As it can be seen from Table 3, an increase in level of irrigation water enhanced the dry matter production. Significantly higher dry matter production was obtained from the optimum irrigation (12.12 t/ha) and 50\% deficit at the initial and the late season stages, $11.77 \mathrm{t} / \mathrm{ha}$ and $11.24 \mathrm{t} / \mathrm{ha}$, respectively

Table 4 presents the irrigation water use efficiency (IWUE) of maize under different levels and timings of irrigation. Applying only $25 \%$ of the full irrigation throughout the whole growing season (T2) resulted in the highest water use efficiency (1.78 $\left.\mathrm{kg} / \mathrm{m}^{3}\right)$. All deficit irrigations increased the water use efficiency from a minimum of $5.2 \%$ in $\mathrm{T} 7$ (50\% deficit at the initial stage) to a maximum of $72 \%$ in $\mathrm{T} 2(75 \%$ deficit throughout the growing season). Higher water use efficiencies were obtained by stressing the crop by $75 \%$ at individual growth stages than stressing by $50 \%$. At the mid season stage, even if its water use efficiency is lower, it is better to stress the crop by $50 \%$ deficit than by $75 \%$ deficit. In T4 and T8, there was an expected yield of 
94.8\% and 98.3\%. In treatment $\mathrm{T} 3$ and $\mathrm{T} 7$ the IWUE was 1.12 and 1.09 times higher than T1. This suggests that increasing the areas irrigated with the water saved would compensate for any yield loss.

\section{DISCUSSION}

Stressing the crop during mid season stage reduced the yield significantly as compared to stressing the crop during the initial and late season stages. This stage has also the highest yield response factor $\left(\mathrm{K}_{\mathrm{y}}=1.3\right)$ than the other three stages [21]. The most sensitive periods are those which correspond to flowering stage and root growth [22]. When a severe stress follows, the crop rapidly depletes the soil water stored in the root zone and wilts before the completion of additional root development at greater soil depths [22]. From deficit irrigation experiments on vegetables and cereals, it was found that lowest yield is obtained during the full stress $(75 \%$ deficit) throughout the growing season; however, stressing the crops during initial and late season stage of the growing season does not affect the crop yield significantly [23].

$\mathrm{T} 4$ and $\mathrm{T} 8$ received adequate irrigation during the initial, mid season stage and late season stage. The crop partially recovered from the stress during the development stage as indicated by its higher yield, $6.74 \mathrm{t} / \mathrm{ha}$ and $6.99 \mathrm{t} / \mathrm{ha}$ respectively, which was higher than that of T5 and T9. The ability of crops to partially recover the effect of early water stress has also been observed in other studies [22]. These studies revealed that under limited water conditions, it is better to start subjecting the crops to stress early in the season. By doing so, the crop adapts to limited watering conditions with the stress not being severely concentrated in any one time period.

Analysis of variance revealed that total biomass production was significantly $(\mathrm{p}<0.01)$ influenced by variation in level of water application. The biomass production in the experiment was proportional to the availability of water. As the stress intensity increased, biomass production decreased. These findings were in agreement with the experimental results reported in other studies which attributed lower leaf production and dry matter to water stress $[24,25]$. A maximum biomass yield $(25.89 \mathrm{t} / \mathrm{ha})$ was obtained from treatment 1 , whereas the minimum biomass yield (16.36 t/ha) was obtained from T2 (75\% deficit throughout the growth season). Other studies in the area also found that biomass production per plant of haricot bean was significantly reduced due to soil moisture stress [26].

Since dry matter accumulation is the balance between photosynthesis and respiration, any activity that promotes photosynthesis and decreases respiration will usually increase dry matter production. Hence, as an increase in amount of water application favours photosynthesis rate and decreases respiration rate, it results in high dry matter production. Soil moisture stress during vegetative and reproductive stages results in the reduction of above ground dry weight [26, 27].

In this study the term irrigation water use efficiency (IWUE) was used instead of the traditional water use efficiency (WUE). This was thought to be better because not all

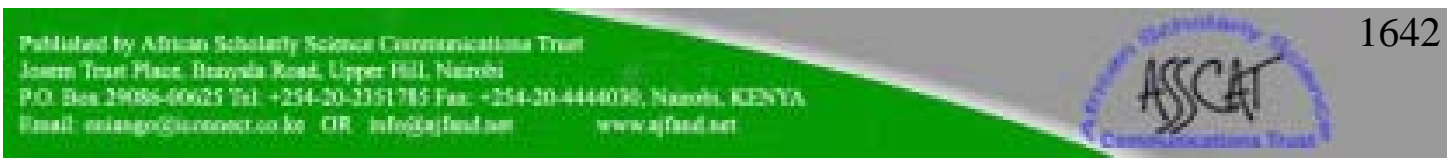


irrigation water is used in the evapotranspiration processes, a fraction of the ETc comes from sources other than irrigation and the former can help to evaluate the productivity of irrigation [28]. Treatments which received lower amount of water resulted in higher IWUE. Higher water use efficiency is obtained from stressing the crop by $75 \%$ deficit at individual stage than stressing by $50 \%$ deficit. At the mid season stage since the crop is highly sensitive to water stress, even if its water use efficiency is lower, it is better to stress the crop at $50 \%$ deficit in order to have lower yield reduction $(10.5 \%)$.

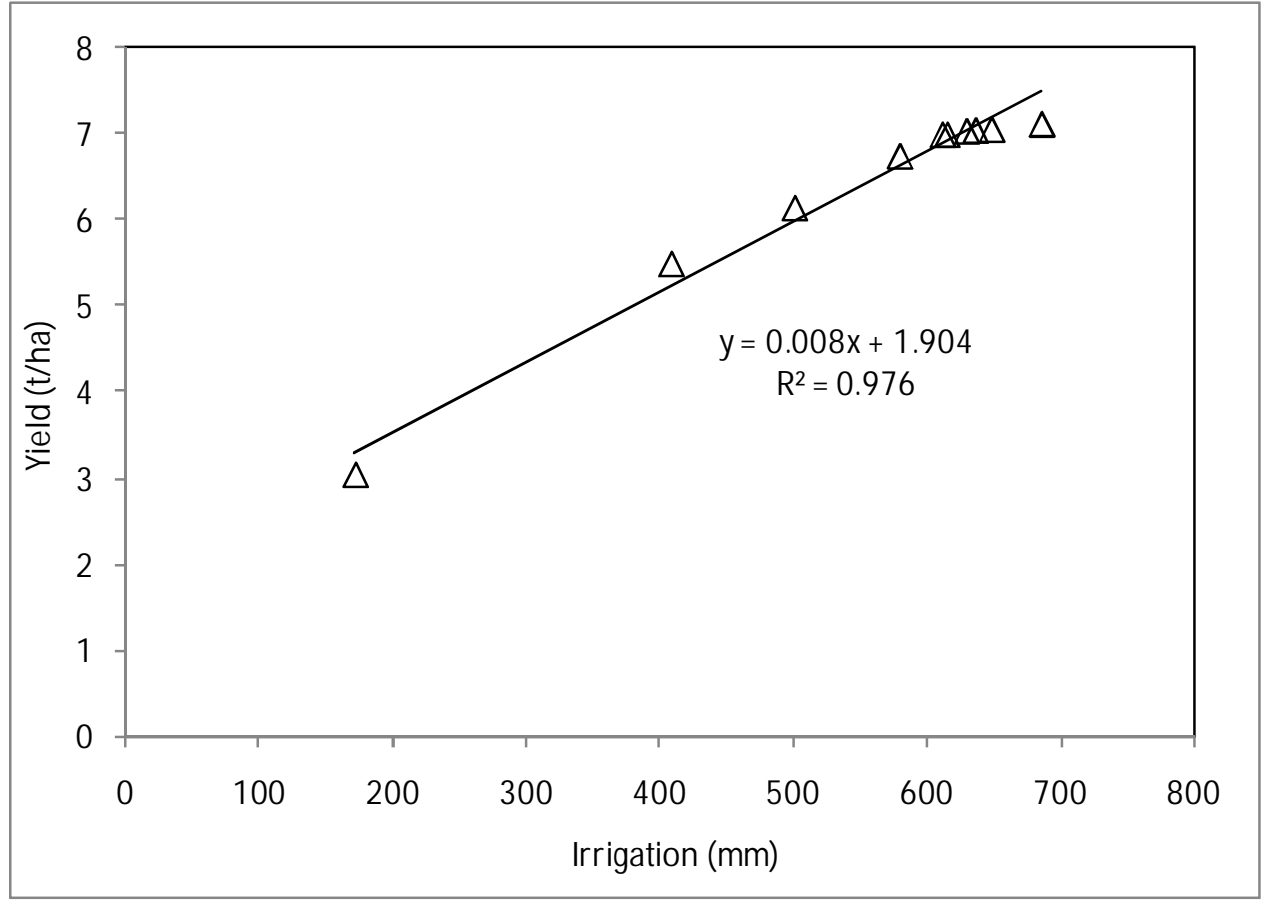

Figure 2: Yield-irrigagtion relationship

Linear relationship was found between yield and seasonal irrigation (Fig. 2). Some studies have found similarly good linear relationships between yield and irrigation water applied in maize subject to deficit irrigation treatments [29, 30]. However, other studies found non-linear relationship between yield and seasonal irrigation [28, 31]. The relationship between yield and irrigation is affected by factors such as climate, soil properties and irrigation practices [12]. These factors should be taken into account when proposing deficit irrigation strategies.

\section{CONCLUSION}

Maximum maize biomass yield, grain yield and stover yield are obtained by applying optimum amount of water throughout the growing season. Fifty percent irrigation at the initial and late season stages resulted in statistically similar average grain yield and biomass as that of applying full irrigation requirement throughout the whole season. Meeting full water requirement during the first two growth stages of maize is 


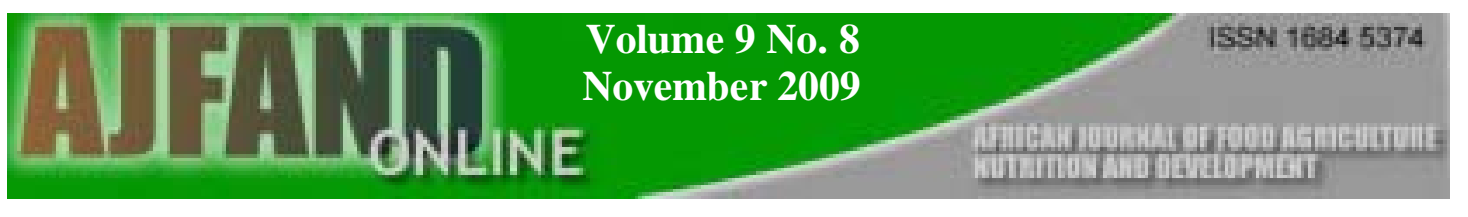

not advisable if water shortage cannot be avoided during the remainder of the season, especially during the mid season stage. However, stressing maize either by one-half or three-quarters at the mid season stage results in lower yields next to stressing the crop throughout the growing season. This indicates that the most critical period for irrigation is the mid season stage. However, if water stress is unavoidable at the mid stage, it is better to stress the crop one-half deficit than by three-quarters. When water stress is imposed early in the growing season, high yield of maize could easily be sustained provided adequate watering conditions take place during the rest of the growing season.

Maize water use efficiency is lowest when optimum or maximum irrigation water is applied throughout the growth season and highest when water is stressed by threequarter throughout the growing season. Higher water use efficiency can be obtained by stressing maize crop by three-quarter deficit at individual growth stages than stressing by one-half deficit.

Overall, a strategy of stressing maize by one-half at the beginning and end of season, and using the water to irrigate a greater area, results in higher aggregate production than providing optimum irrigation throughout the season for a smaller area. 
Table 1: Description of irrigation treatments for deficit irrigation on maize at Dire Dawa, Ethiopia

\begin{tabular}{|c|c|c|c|c|c|}
\hline \multirow[b]{2}{*}{ Treatment } & \multicolumn{4}{|c|}{ Growth stage/period } & \multirow[b]{2}{*}{ Description } \\
\hline & $\mathrm{P} 1$ & $\mathrm{P} 2$ & P3 & $\mathrm{P} 4$ & \\
\hline \multicolumn{6}{|c|}{ Controls } \\
\hline T1 (1111) & 1 & 1 & 1 & 1 & All normal watering \\
\hline $\mathrm{T} 2(0000)$ & 0 & 0 & 0 & 0 & All stress ( $75 \%$ deficit) \\
\hline \multicolumn{6}{|c|}{ One period of stress with ( $75 \%$ deficit) } \\
\hline T3 (0111) & 0 & 1 & 1 & 1 & Stress during P1 \\
\hline T4 (1011) & 1 & 0 & 1 & 1 & Stress during P2 \\
\hline T5 (1101) & 1 & 1 & 0 & 1 & Stress during P3 \\
\hline T6 (1110) & 1 & 1 & 1 & 0 & Stress during P4 \\
\hline \multicolumn{6}{|c|}{ One period of stress with (50\% deficit) } \\
\hline T7 (0111) & 0 & 1 & 1 & 1 & Stress during P1 \\
\hline T8 (1011) & 1 & 0 & 1 & 1 & Stress during P2 \\
\hline T9 (1101) & 1 & 1 & 0 & 1 & Stress during P3 \\
\hline T10 (1110) & 1 & 1 & 1 & 0 & Stress during P4 \\
\hline
\end{tabular}




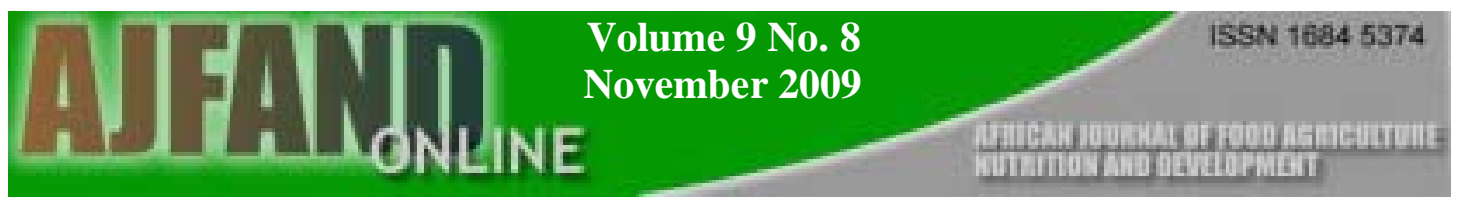

Table 2: Irrigation scheduling and amount of water applied for each treatment (mm) of maize crop at Dire Dawa, Ethiopia

\begin{tabular}{|c|c|c|c|c|c|c|c|c|c|c|c|}
\hline Date & $\begin{array}{c}\text { Irrigation } \\
\text { Interval } \\
(\text { days })\end{array}$ & $\begin{array}{c}\mathrm{KT} 100 \\
(\mathrm{~T} 1)\end{array}$ & $\begin{array}{c}\mathrm{KT} 25 \\
(\mathrm{~T} 2)\end{array}$ & $\begin{array}{c}\mathrm{T}_{1} 25 \\
(\mathrm{~T} 3)\end{array}$ & $\begin{array}{c}\mathrm{T}_{2} 25 \\
(\mathrm{~T} 4)\end{array}$ & $\begin{array}{c}\mathrm{T}_{3} 25 \\
(\mathrm{~T} 5)\end{array}$ & $\begin{array}{c}\mathrm{T}_{4} 25 \\
(\mathrm{~T} 6)\end{array}$ & $\begin{array}{c}\mathrm{T}_{1} 50 \\
(\mathrm{~T} 7)\end{array}$ & $\begin{array}{c}\mathrm{T}_{2} 50 \\
(\mathrm{~T} 8)\end{array}$ & $\begin{array}{c}\mathrm{T}_{3} 50 \\
(\mathrm{~T} 9)\end{array}$ & $\begin{array}{c}\mathrm{T}_{4} 50 \\
(\mathrm{~T} 10)\end{array}$ \\
\hline 3 Nov & 0 & 5.2 & 1.3 & 1.3 & 5.2 & 5.2 & 5.2 & 2.6 & 5.2 & 5.2 & 5.2 \\
\hline 10 Nov & 7 & 35.3 & 8.8 & 8.8 & 35.3 & 35.3 & 35.3 & 17.7 & 35.3 & 35.3 & 35.3 \\
\hline 17 Nov & 7 & 34.5 & 8.6 & 8.7 & 34.5 & 34.5 & 34.5 & 17.3 & 34.5 & 34.5 & 34.5 \\
\hline 24 Nov & 7 & 39.0 & 9.8 & 39.0 & 9.7 & 39.0 & 39.0 & 39.0 & 19.5 & 39.0 & 39.0 \\
\hline 1 Oct & 7 & 47.3 & 11.8 & 47.3 & 11.8 & 47.3 & 47.3 & 47.3 & 23.7 & 47.3 & 47.3 \\
\hline 8 Oct & 7 & 55.3 & 13.8 & 55.3 & 13.8 & 55.3 & 55.3 & 55.3 & 27.7 & 55.3 & 55.3 \\
\hline 15 Oct & 7 & 62.2 & 15.6 & 62.2 & 62.2 & 15.6 & 62.2 & 62.2 & 62.2 & 31.1 & 62.2 \\
\hline 22 Oct & 7 & 62.3 & 15.6 & 62.3 & 62.3 & 15.6 & 62.3 & 62.3 & 62.3 & 31.2 & 62.3 \\
\hline 29 Oct & 7 & 61.5 & 15.4 & 61.5 & 61.5 & 15.4 & 61.5 & 61.5 & 61.5 & 30.8 & 61.5 \\
\hline 5 Jan & 7 & 61.0 & 15.3 & 61.0 & 61.0 & 15.3 & 61.0 & 61.0 & 61.0 & 30.5 & 61.0 \\
\hline 12 Jan & 7 & 61.3 & 15.3 & 61.3 & 61.3 & 15.3 & 61.3 & 61.3 & 61.3 & 30.7 & 61.3 \\
\hline 19 Jan & 7 & 62.0 & 15.5 & 62.0 & 62.0 & 15.5 & 62.0 & 62.0 & 62.0 & 31.0 & 62.0 \\
\hline 26 Jan & 7 & 57.7 & 14.4 & 57.7 & 57.7 & 57.7 & 14.4 & 57.7 & 57.7 & 57.7 & 28.8 \\
\hline 2 Feb & 7 & 41.5 & 10.4 & 41.5 & 41.5 & 41.5 & 10.4 & 41.5 & 41.5 & 41.5 & 20.8 \\
\hline Total & 95 & 686.2 & 171.6 & 629.9 & 579.8 & 408.5 & 611.8 & 648.7 & 615.3 & 501.0 & 636.6 \\
\hline
\end{tabular}

Note: KT100=Optimum irrigation, KT25=75\% deficit throughout, $\mathrm{T}_{1} 25, \mathrm{~T}_{2} 25, \mathrm{~T}_{3} 25, \mathrm{~T}_{4} 25$ and $\mathrm{T}_{1} 50$,

$\mathrm{T}_{2} 50, \mathrm{~T}_{3} 50, \mathrm{~T}_{4} 50$ are treatments with

$75 \%$ deficit and 50\% deficit respectively, at initial stage, development stage, mid season stage and late season stage 
Table 3: Statistical analysis of different levels of irrigation on maize yield and yield components

\begin{tabular}{|c|c|c|c|c|}
\hline Treatment & $\begin{array}{c}\text { Grain yield } \\
(\mathrm{t} / \mathrm{ha})^{* *}\end{array}$ & $\begin{array}{c}\text { Biomass yield } \\
(\mathrm{t} / \mathrm{ha})^{* *}\end{array}$ & $\begin{array}{c}\text { Stover yield } \\
(\mathrm{t} / \mathrm{ha})^{* *}\end{array}$ & $\begin{array}{c}\text { Dry matter } \\
(\mathrm{t} / \mathrm{ha})^{* *}\end{array}$ \\
\hline KT100(T1) & $7.110^{\mathrm{a}}$ & $25.890^{\mathrm{a}}$ & $13.640^{\mathrm{a}}$ & $12.120^{\mathrm{a}}$ \\
\hline KT25 (T2) & $3.048^{\mathrm{e}}$ & $16.360^{\mathrm{e}}$ & $8.044^{\mathrm{e}}$ & $6.080^{\mathrm{g}}$ \\
\hline $\mathrm{T}_{1} 25(\mathrm{~T} 3)$ & $7.030^{\mathrm{a}}$ & $21.690^{\mathrm{bc}}$ & $11.650^{\mathrm{bc}}$ & $10.380^{\mathrm{cd}}$ \\
\hline $\mathrm{T}_{2} 25(\mathrm{~T} 4)$ & $6.738^{\mathrm{b}}$ & $21.710^{\mathrm{bc}}$ & $10.670^{\mathrm{cd}}$ & $9.514^{\mathrm{de}}$ \\
\hline $\mathrm{T}_{3} 25(\mathrm{~T} 5)$ & $5.494^{\mathrm{d}}$ & $18.450^{\mathrm{de}}$ & $8.822^{\mathrm{e}}$ & $8.137^{\mathrm{f}}$ \\
\hline $\mathrm{T}_{4} 25(\mathrm{~T} 6)$ & $6.986^{\mathrm{a}}$ & $21.890^{\mathrm{bc}}$ & $10.600^{\mathrm{cd}}$ & $10.530^{\mathrm{bcd}}$ \\
\hline $\mathrm{T}_{1} 50(\mathrm{~T} 7)$ & $7.057^{\mathrm{a}}$ & $21.220^{\mathrm{bcd}}$ & $12.640^{\mathrm{ab}}$ & $11.711^{\mathrm{ab}}$ \\
\hline $\mathrm{T}_{2} 50(\mathrm{~T} 8)$ & $6.991^{\mathrm{a}}$ & $23.200^{\mathrm{ab}}$ & $11.510^{\mathrm{bc}}$ & $10.610^{\mathrm{bcd}}$ \\
\hline $\mathrm{T}_{3} 50(\mathrm{~T} 9)$ & $6.139^{\mathrm{c}}$ & $19.650^{\mathrm{cd}}$ & $9.222^{\mathrm{de}}$ & $8.666^{\mathrm{ef}}$ \\
\hline $\mathrm{T}_{4} 50(\mathrm{~T} 10)$ & $7.041^{\mathrm{a}}$ & $22.820^{\mathrm{b}}$ & $11.680^{\mathrm{bc}}$ & $11.240^{\mathrm{abc}}$ \\
\hline $\mathrm{LSDD}^{\mathrm{b}}(0.05)$ & 191.7 & 27.39 & 138.5 & 112.1 \\
\hline $\mathrm{CV}^{\mathrm{b}}(\%)$ & $1.76^{\mathrm{b}}$ & 7.5 & 7.44 & 6.60 \\
\hline
\end{tabular}

* Treatment means followed by the same letter(s) are not significantly different at a given level of significant $* *$ Average of three replications 


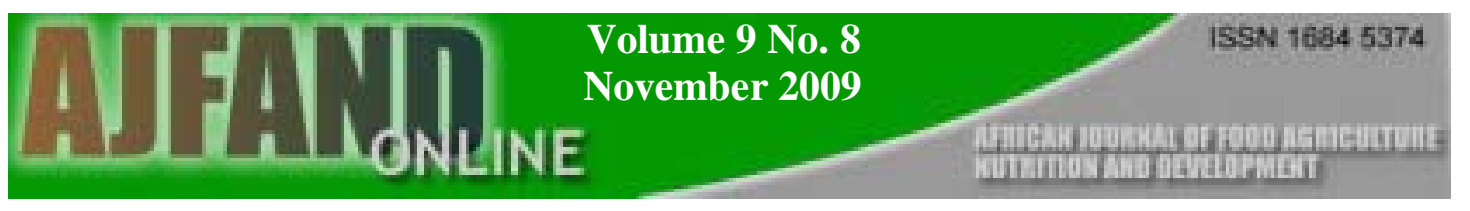

Table 4: Yield and water use efficiency of maize crop at Dire Dawa, Ethiopia

\begin{tabular}{|c|c|c|c|c|c|c|c|}
\hline Treatment & $\begin{array}{c}\text { Yield } \\
(\mathrm{t} / \mathrm{ha})\end{array}$ & $\begin{array}{c}\text { Irrigation } \\
\left(\mathrm{m}^{3} / \mathrm{ha}\right)\end{array}$ & $\begin{array}{c}\text { IWUE } \\
\left(\mathrm{t} / \mathrm{m}^{3}\right) * 10^{-3}\end{array}$ & $\begin{array}{c}\text { Water } \\
\text { saved }(\%)\end{array}$ & $\begin{array}{c}\text { Yield } \\
\text { reduction }(\%)\end{array}$ & $\begin{array}{c}\text { Rank on } \\
\text { Yield }\end{array}$ & $\begin{array}{c}\text { Rank on } \\
\text { IWUE }\end{array}$ \\
\hline $\mathrm{KT} 100(\mathrm{~T} 1)$ & 7.11 & 6862 & 1.04 & 0 & 0 & 1 & 10 \\
\hline $\mathrm{KT} 25(\mathrm{~T} 2)$ & 3.05 & 1716 & 1.78 & 51.5 & 57.1 & 10 & 1 \\
\hline $\mathrm{T}_{1} 25(\mathrm{~T} 3)$ & 7.03 & 6299 & 1.12 & 5.6 & 1.1 & 4 & 7 \\
\hline $\mathrm{T}_{2} 25(\mathrm{~T} 4)$ & 6.74 & 5798 & 1.16 & 10.6 & 5.2 & 7 & 4 \\
\hline $\mathrm{T}_{3} 25(\mathrm{~T} 5)$ & 5.49 & 4085 & 1.34 & 27.8 & 22.7 & 9 & 2 \\
\hline $\mathrm{T}_{4} 25(\mathrm{~T} 6)$ & 6.99 & 6118 & 1.14 & 7.4 & 1.7 & 6 & 5 \\
\hline $\mathrm{T}_{1} 50(\mathrm{~T} 7)$ & 7.05 & 6487 & 1.09 & 3.8 & 0.7 & 2 & 9 \\
\hline $\mathrm{T}_{2} 50(\mathrm{~T} 8)$ & 6.99 & 6153 & 1.14 & 7.1 & 1.7 & 5 & 6 \\
\hline $\mathrm{T}_{3} 50(\mathrm{~T} 9)$ & 6.14 & 5010 & 1.23 & 18.5 & 13.6 & 8 & 3 \\
\hline $\mathrm{T}_{4} 50(\mathrm{~T} 10)$ & 7.04 & 6366 & 1.11 & 5.0 & 0.9 & 3 & 8 \\
\hline
\end{tabular}




\section{REFERENCES}

1. Oweis $\mathbf{T}$ and $\mathbf{H}$ Zhang Water-use efficiency: index for optimizing supplemental irrigation of wheat in water scarce areas. Zeitchrift f. Bewaesserungswirtschaft. 1998; 33(2):321-336.

2. Zhang H, Oweis $\mathbf{T}$, Garabet $\mathbf{S}$ and $\mathbf{M}$ Pala Water-use efficiency and transpiration efficiency of wheat under rain-fed conditions and supplemental irrigation in a Mediterranean type environment. Plant Soil. 1998; 201:295-305.

3. Smith M, Kivumbi D and LK Heng Use of FAO CROPWAT model in deficit irrigation studies. Pp 17-27. In: Deficit irrigation practice. FAO Water Report No 22. FAO, Rome, 2002.

4. Rao NH Irrigation scheduling of rice with a crop growth stimulation model. Agri. Sys. 1992; 39:115-132.

5. Mulatu K, Bohale G, Worku M, Desalegn Y and A Afete Maize production trends and research in Ethiopia. Paper presented to the first national maize workshop. May, 1992. Addis Ababa, Ethiopia.

6. Pandey RK, Maranville JW and A Admou Deficit irrigation and nitrogen effects on maize in a Sahelian environment. I. Grain yield and yield components. Agricultural Water Management. 2000; 46:1-13.

7. Cakir R Effect of water stress at different development stages on vegetative and reproductive growth of corn. Field Crops Res. 2004; 89:1-6.

8. Bolanos J and GO Edmeas Eight cycle of selection for drought tolerance in low land tropical maize. In: CIMMYT, Response in grain yield, biomass and radiation utilization. Mexico. 1993.

9. Duncken WG Maize in crop physiology. Some Case Histories. Cambridge Univ. Press, London. 1975.

10. Shaw RH Climate requirement. In: Sparague, G.F. and J.W. Dudley (eds). 1988. Wisconsin, USA.

11. Denmead OT and RH Shaw The effects of soil moisture stress at different stages of growth on the development and yield of corn. Agron. J. 1960.

12. Farre I and JM Faci Deficit irrigation in maize for reducing agricultural water use in a Mediterranean environment. Agricultural Water Management. 2009; 96:383-394.

13. Scheierling SM, Cardon GE and RA Young Impact of irrigation timing on simulated water-crop production functions. Irrigation Sci. 1997; 18:23-31. 
14. Pandey RK, Maranville JW and MM Chetima Deficit irrigation and nitrogen effects on maize in a Sahelian environment II. Shoot growth, nitrogen uptake and water extraction. Agricultural Water Management. 2000; 46:15-27.

15. El-Tantawy MM, Ouda SA, FA Khalil Irrigation scheduling for maize grown under Middle Egypt conditions. Research Journal of Agricultural and Biological Sciences. 2007; 3(5):456-462.

16. Payero JO, Melvin SR, Irmak S and D Tarkalson Yield response of corn to deficit irrigation in a semiarid climate. Agricultural Water Management. 2006; 84:1-2.

17. Klocke NL, Schneekloth JP, Melvin S, Clark RT and JO Payero Field scale limited irrigation scenarios for water policy strategies. Appl. Eng. Agric. 2004; 22:623-631.

18. Mamo A Technical and Economical Feasibility of Small Holder Drip Irrigation using Harvested Rainwater for Onion Production at Dire Dawa. MSc. Thesis, Alamaya University, Ethiopia. 2005.

19. Allen RG, Pereira LS, Raes D and M Smith Crop evapotranspiration: guidelines for computing crop requirements. FAO Irrigation and Drainage Paper 56. FAO, Rome, 1998.

20. Bakker DM, Raine SR and MJ Robertson A preliminary Investigation of Alternate Furrow Irrigation for Sugar Cane Production. 1999. http://www.usq.edu.au/users/raine/index fiels/ASSCT 97.Bakker et al., pdf.

21. Doorenbos $\mathbf{J}$ and $\mathbf{A H}$ Kassam Yield response to water. FAO Irrigation and Drainage Paper 33. FAO, Rome. 1979.

22. Kirda $\mathbf{C}$ and $\mathbf{R}$ Kanber Water, no longer a plentiful resource, should be used sparingly in irrigated agriculture. In: C. Kirda, P. Moutonnet, C. Hera \& D.R. Nielsen (eds.). Crop yield response to deficit irrigation, Dordrecht, The Netherlands, Kluwer Academic Publishers. 1999.

23. Bazza $\mathbf{M}$ and $\mathbf{M}$ Tayaa Contribution to improve sugar beet deficit-irrigation. In: C. Kirda, P. Moutonnet, C. Hera, D.R. Nielsen, eds. Crop yield response to deficit irrigation, Dordrecht, The Netherlands, Kluwer Academic Publishers. 1999.

24. Pandy RK, Herrera WAT, Villegas AN and JW Pendleton Drought response of grain legumes under irrigation gradient: II. Plant water status and canopy temperature. Agronomy Journal. 1983;76: 553-557. 
25. EI-Bagoury $\mathbf{O H}$ and $\mathbf{A M}$ Shaheen Germination and Seedling characteristics response of five crop species to water deficit. Seed science and technology. 1977; 5(3):527-537. (15).

26. Tesfaye $\mathbf{K}$ Influence of soil water deficit on the development, yield and yield components of haricot bean at different stage of growth. MSc. Thesis, Alemaya University, Alemaya, Ethiopia, 1997.

27. Marouelli WA, Giordano LB, Olivera CAD and OA Carrijo Development yield and quality of peas under different soil water tensions. Field Crop Abstracts. 1991; 46(1), 42.

28. Tolk JA and TA Howell Water use efficiencies of grain sorghum grown in three USA Southern great plains soils. Agricultural Water Management. 2003; 59:97-111.

29. Payero JO, Melvin SR, Irmak S and D Tarkalson Yield response of corn to deficit irrigation in a semiarid climate. Agricultural Water Management. 2006; 84:101-112.

30. Farre I and JM Faci Comparative response of maize (Zea mays L.) and sorghum (Sorghum bicolor L. Moench) to deficit irrigation in a Mediterranean environment. Agricultural Water Management. 2006; 83:135-143.

31. Mantovani EC, Villalobos FJ, Orgaze F and E Fereres Modeling the effects of sprinkler irrigation uniformity on crop yield. Agricultural Water Management. 1995; 27:243-257. 